\title{
Water Status of Rhizobia in Relation to their Susceptibility to Desiccation and to their Protection by Montmorillonite
}

\author{
By H. V. A. BUSHBY* AND K. C. MARSHALL $\dagger$ \\ Department of Agricultural Science, University of Tasmania, \\ Hobart, Tasmania 7000, Australia
}

(Received 8 June 1976)

SUMMARY

The greater susceptibility to desiccation of the Rhizobium leguminosarum group of rhizobia compared with the slow-growing rhizobia is related to the different amounts of water retained by these groups of bacteria at any relative vapour pressure, rather than differences in rates of water movement into or out of the bacteria. The higher retention of water by the $R$. leguminosarum group at any relative vapour pressure is related to greater availability of adsorptive surface area, and to higher surface energies resulting in a greater affinity for water. Although the internal osmotic pressure is greater in the slow-growing group than in the $R$. leguminosarum group, it is concluded that differences in internal solute concentrations cannot account for the different adsorption isotherms found for these groups.

Montmorillonitic clay protects the fast-growing $R$. leguminosarum group from the effects of desiccation, but not the slow-growing group. Ca-montmorillonite retains greater quantities of water at any relative vapour pressure than either group of bacteria. Possible mechanisms of protection of the bacteria by the clay are discussed in terms of relative affinities for water under desiccation conditions.

\section{INTRODUCTION}

The fast-growing clover, pea and a lotus root-nodule bacteria (referred to subsequently as the Rhizobium leguminosarum group) are more susceptible to the effects of desiccation in sandy soil than the slow-growing group of rhizobia. Montmorillonitic clay provides a degree of protection against desiccation damage to the $R$. leguminosarum group but not to the slow-growing group (Marshall, 1964; Bushby \& Marshall, 1976). The purpose of the present investigation was to examine these differences between the $R$. leguminosarum and slow-growing groups of rhizobia in terms of the water status of the cells. The two groups of rhizobia have been compared on the basis of the amounts of water retained by the cells over a range of relative vapour pressures. In addition, rates of water loss by rhizobia have been examined and compared with those in other bacteria and a yeast.

\section{METHODS}

Organisms and cultural conditions. Cultures used in these experiments are described where appropriate in Results. The rhizobia were grown as described previously (Bushby \& Marshall, 1976). Escherichia coli MI3, Staphylococcus aureus M3 and Bacillus sp. M70 were grown at $28^{\circ} \mathrm{C}$ on nutrient broth or agar; Saccharomyces cerevisiae $\mathrm{m} 6$ was grown at $28^{\circ} \mathrm{C}$ on malt

* Present address: CSIRO, Division of Tropical Agronomy, St Lucia, Queensland 4067, Australia.

† Present address: School of Microbiology, The University of New South Wales, Kensington, N.S.W. 2033, Australia. 
extract broth or agar. Bacillus $\mathbf{M} 70$ did not form spores after $24 \mathrm{~h}$ under the conditions used.

Microbial counts and dimensions. Total counts of micro-organisms were made using a Petroff-Hauser counting chamber and viable counts were made by plating serial decimal dilutions in duplicate or triplicate. The dimensions of individual micro-organisms were measured using a filar micrometer; averages of 20 measurements were used to calculate surface areas and volumes. Rod-shaped bacteria were assumed to be closed cylinders, and the yeast was assumed to be spherical.

Internal osmotic pressures of micro-organisms. The internal osmotic pressures were determined by two methods. (I) Micro-organisms were centrifuged and resuspended in a minimum volume of water. The packed cell volumes were determined by standard haematocrit techniques. Micro-organisms in the suspensions were then disrupted by sonication and/or autoclaving and the cell debris was removed by centrifugation. The osmolalities of the supernatants were determined using a model G62 Fiske osmometer; the results were expressed as milliosmol (mosmol) per unit packed cell volume (PCV). The large amount of extracellular polysaccharide produced by many species of Rhizobium gave highly viscous suspensions and resulted in erroneous PCV results.

(2) Micro-organisms were harvested from agar slopes using a minimum volume of distilled water, and the number of viable organisms $\mathrm{ml}^{-1}$ was determined. The suspension was frozen at $-20^{\circ} \mathrm{C}$ and then lyophilized. Micro-organisms dried in this way were rehydrated and disrupted in a known volume of the detergent Triton X-100 (BDH), and the cell debris was removed by centrifugation. The osmolalities of the supernatants were measured and expressed as mosmol per unit $\log _{10}$ of the viable count.

Water permeabilities of micro-organisms as determined by nuclear magnetic resonance (n.m.r.) spectroscopy. Water permeabilities of micro-organisms were determined by the method of Conlon \& Outhred (1972), using a steady-state, high-resolution JEOL model ${ }_{4} \mathrm{HI} 00$ n.m.r. spectrometer operated at I00 MHz. For the reasons outlined by Pople, Schneider \& Bernstein (1959), inclusion of particulate matter such as living organisms in the sample leads to errors in the spectra when steady-state n.m.r. is used. Hence the estimates of $T_{2}$ (spin-spin relaxation time) in the present investigation are only relative, and not absolute, measurements of the water permeability of cells.

Packed cell volumes were determined for all cultures used and the internal osmotic pressures were measured by method (I) to calculate the concentrations of $\mathrm{MnCl}_{2} \cdot 6 \mathrm{H}_{2} \mathrm{O}$ required to yield isotonic solutions. Double-strength stock solutions were used so that the final concentration on mixing with the cell suspensions $(50 \%, v / v)$ yielded isotonic solutions. Within 2 min of mixing the suspensions with $\mathrm{Mn}^{2+}$, the n.m.r. spectra were recorded using $0.5 \mathrm{ml}$ samples in standard high-resolution n.m.r. tubes.

Water sorption isotherms of rhizobia and montmorillonite. The apparatus used to obtain the sorption isotherms was similar to the silica spring balance described by Bateman et al. (1962). The water temperature in the jacket was maintained at $40^{\circ} \mathrm{C}$. Bovine serum albumin was used to check that the apparatus was functioning properly and the values obtained were in good agreement with those reported by Bull (I944). A complete adsorption-desorption cycle for $R$. japonicum QA372 showed the hysteresis phenomenon common to such isotherms.

The B.E.T. theory (Brunauer, Emmett \& Teller, 1938) has been applied to the data from the water adsorption isotherms for rhizobia and montmorillonite. The B.E.T. equation states that:

$$
\frac{P / P_{0}}{W\left(\mathrm{I}-P / P_{0}\right)}=\frac{(C-\mathrm{I})}{W_{\mathrm{m}} C} P / P_{0}+\frac{\mathrm{I}}{W_{\mathrm{m}} C}
$$

in which $W$ is the amount of water vapour sorbed per $100 \mathrm{~g}$ dry weight at a pressure $P$, 
$P_{0}$ is the saturation vapour pressure, $W_{\mathrm{m}}$ is the amount of water required to form a monolayer over the adsorbing surface, and $C$ is a constant from which the heat of adsorption for the monolayer can be obtained. Values of $W_{\mathrm{m}}$ and $C$ can be calculated from a plot of $\left.\left[P / P_{0}\right] / W\left(\mathrm{I}-P / P_{0}\right)\right]$ against $P / P_{0}$.

The change in free energy involved when proteins (Bull, I944) or montmorillonite (Roderick \& Demirel, 1966) adsorb water vapour has been determined by application of Bangham's (1937) free-energy equation to the isotherm data. This equation can be expressed as:

$$
\Delta F=\frac{-R T}{M A} \int_{0}^{1} \frac{W}{P / P_{0}} \mathrm{~d}\left(P / P_{0}\right)
$$

in which $R$ is the gas constant, $T$ is the absolute temperature, $M$ is the molecular weight of water, $A$ is the specific surface area of the adsorbing material, $W$ is the weight of water adsorbed per $100 \mathrm{~g}$ dry weight at a pressure $P, P_{0}$ is the saturation vapour pressure, and $\Delta F$ is the change in free energy involved with wetting. The equation states that $\Delta F$ is proportional to the area under the curve in a plot of $W /\left(P / P_{0}\right)$ against $P / P_{0}$.

Bull \& Breese (1970), Walker, Wolf \& Kapsalis (1973) and Steer (1973) noted that the presence of residual salt markedly affected the water sorption isotherms of various proteins. To determine whether this was an important factor in the water sorption characteristics of both groups of rhizobia, the isotherms of salt-free suspensions of the bacteria were obtained. Rhizobia were disrupted using Triton X-I00, suspensions were dialysed thoroughly at $2{ }^{\circ} \mathrm{C}$ and freeze-dried, and the water sorption isotherms were determined.

\section{RESULTS}

\section{Osmolality of the internal contents of rhizobia}

The internal solute concentrations of various species of Rhizobium relative to packed cell volume or viable count measurements are given in Table $\mathrm{I}$. No correction has been made for the dilution effect of extracellular water, but the results obtained give an indication of the relative differences in internal osmolality between different groups of rhizobia. The osmolality of the internal contents of slow-growing rhizobia is higher than that for either the $\boldsymbol{R}$. leguminosarum group or the fast-growing $R$. meliloti group. The fact that all osmotic activity was removed by dialysis suggests that the osmotically active constituents are mainly ionic and not due to osmotically active glycoproteins (DeVries, Komatsu \& Feeney, 1970).

Water permeabilities of various micro-organisms as determined by n.m.r. spectroscopy

The significant features of the steady-state n.m.r. spectra of Saccharomyces cerevisiae м6 and Bacillus $\mathbf{M} 70$ (Fig. I) are the broad lines, attributable to extracellular water in contact with the paramagnetic ions $\left(\mathrm{Mn}^{2+}\right)$, and the relatively narrow lines, which are derived from intracellular water not in contact with $\mathrm{Mn}^{2+}$. A comparison of the spectra in Fig. I reveals that the line due to intracellular water for Bacillus $\mathbf{M} 70$ was broader than the corresponding line for Sacch. cerevisiae M6. The line widths at half peak height were 7.0 and 2.5 p.p.m. for Bacillus $\mathrm{M} 70$ and Sacch. cerevisiae $\mathrm{M6}$, respectively. Estimates of the relative $T_{2}$ values (the water permeability) of these two organisms are presented in Table 2. The ratio of the $T_{2}$ values for yeast relative to Bacillus $M 70$ was about $3 \cdot 0$, suggesting that the rate of passage of water molecules across the membrane of Bacillus M70 was greater than that of Sach. cerevisiae $\mathrm{M6}$.

Unlike the spectra for yeast and Bacillus M7o, it was not possible to distinguish between intra- and extracellular water for Escherichia coli MI3, Staphylococcus aureus M3 and the 
Table I. Relative osmolalities of the internal contents of various rhizobia expressed either per unit packed cell volume (PCV) or per unit $\log _{10}$ of the viable count

Osmolality of internal contents

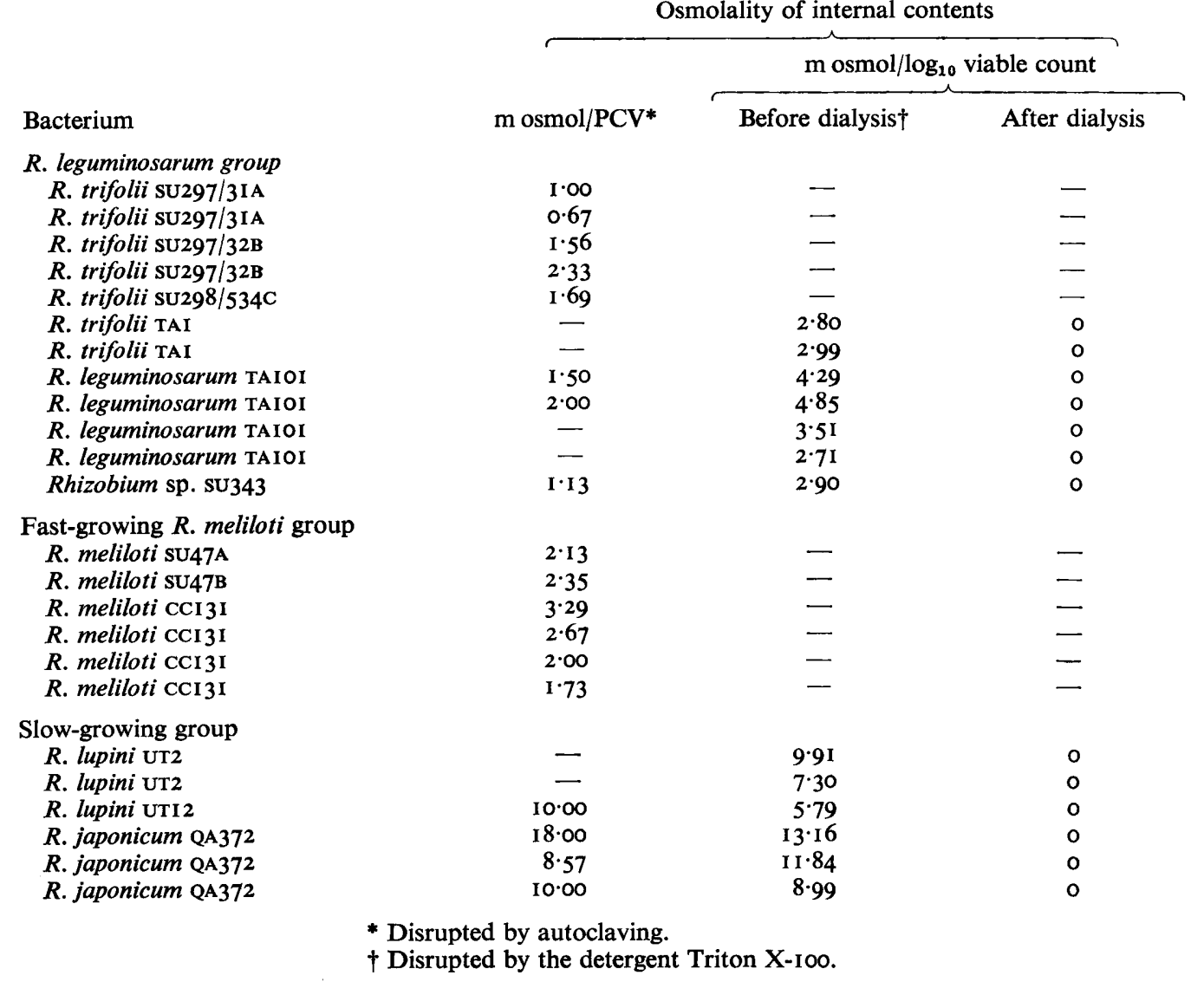

three species of Rhizobium examined. Consequently, relative $T_{2}$ values for these bacteria could not be estimated. At a $\mathrm{Mn}^{2+}$ concentration of $50 \mathrm{mM}$, water would have passed across the membranes of these bacteria in about 0.5 to $I \cdot 0 \mathrm{~ms}(R$. Outhred, personal communication). It appears that the membrane offers very little resistance to the movement of water molecules between the cell interior and the external environment in rhizobia, E. coli and Staph. aureus. Comparison of the surface-to-volume ratios of all the bacteria examined (Table 2) suggests that the estimation of water permeabilities of cells by the n.m.r. technique of Conlon \& Outhred (1972) is limited to micro-organisms with surface-to-volume ratios approximately equal to or less than that of Bacillus M70.

\section{Water adsorption isotherms of rhizobia and Ca-montmorillonite}

Adsorption isotherms of representatives of the $R$. leguminosarum and slow-growing groups of rhizobia, as well as the adsorption isotherm of Ca-montmorillonite, are shown in Fig. 2. The results indicate that bacteria of the $R$. leguminosarum group adsorbed more water per gram than those of the slow-growing group at all relative vapour pressures, except 0.90 and above. The results for Ca-montmorillonite indicate that the clay adsorbed more water per gram than both groups of rhizobia at all relative vapour pressures. 


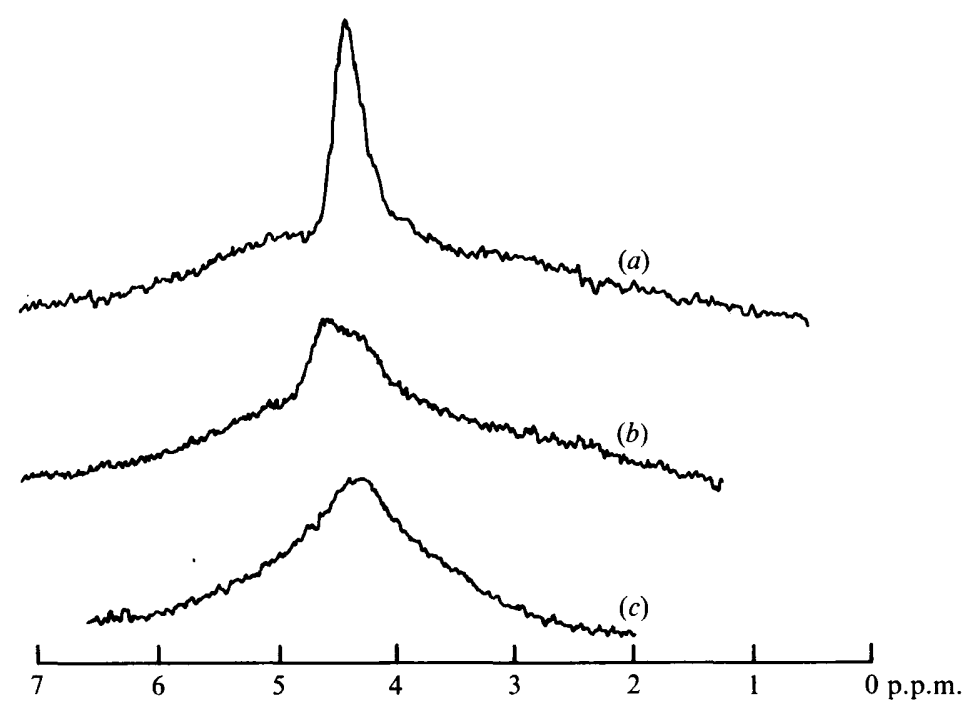

Fig. I. Steady-state n.m.r. spectra of micro-organisms in the presence of paramagnetic $\left(\mathrm{Mn}^{2+}\right)$ ions. Organisms (with concentrations of $\mathrm{MnCl}_{2} \cdot 6 \mathrm{H}_{2} \mathrm{O}$ used in parentheses) were: (a) Sacch. cerevisiae м6 (84 mM); (b) Bacillus M70 (84 mM); (c) R. japonicum QA372 (50 mM).

Table 2. Surface-to-volume ratios and water permeabilities $\left(T_{2}\right.$ values $)$ for various micro-organisms

Organism

Saccharomyces cerevisiae м6

Bacillus sp. M70

Staphylococcus aureus M3

Escherichia coli MI 3

Rhizobium meliloti CCI3I

$R$. japonicum QA372

R. trifolii sU297/32B

$\begin{array}{ccc}\begin{array}{c}\text { Surface-to-volume } \\ \text { ratio }\end{array} & \begin{array}{c}\text { Line width } \\ \text { at half peak } \\ \text { height (p.p.m.) }\end{array} & \begin{array}{c}\text { Relative } \\ T_{2} \\ \text { values }\end{array} \\ 1.27 & 2.5 & 0.1270 \\ 2.97 & 7.0 & 0.0455 \\ 5.45 & * & * \\ 5.93 & * & * \\ 5.93 & * & * \\ 6.86 & * & * \\ 9.46 & * & \end{array}$

* Could not be determined.

The amount of water adsorbed by disrupted bacteria was slightly less than that adsorbed by untreated bacteria. Dialysis of the disrupted suspensions caused a change in both the slope and the position of the isotherms, with the dialysed samples adsorbing more water per gram than the disrupted, undialysed samples (Fig. 3). Obviously, the effect of dialysable solutes was to decrease the amount of water adsorbed by macromolecules of these bacteria.

\section{Calculations based on the water adsorption isotherm}

Application of equation (I) to the water isotherm data in Fig. 2 gave the constants presented in Table 3. The average $W_{\mathrm{m}}$ value for the $R$. leguminosarum group is approximately twice that for the slow-growing group, whereas the $W_{\mathrm{m}}$ value for Ca-montmorillonite is higher than those of both groups of bacteria. The Ca-montmorillonite result is in close agreement with that reported by Roderick \& Demirel (I966).

If it is assumed that the adsorbed water molecules were in the closest packing arrangement, then the average cross-sectional area for a water molecule would be $0.105 \mathrm{~nm}^{2}$ (Roderick \& 


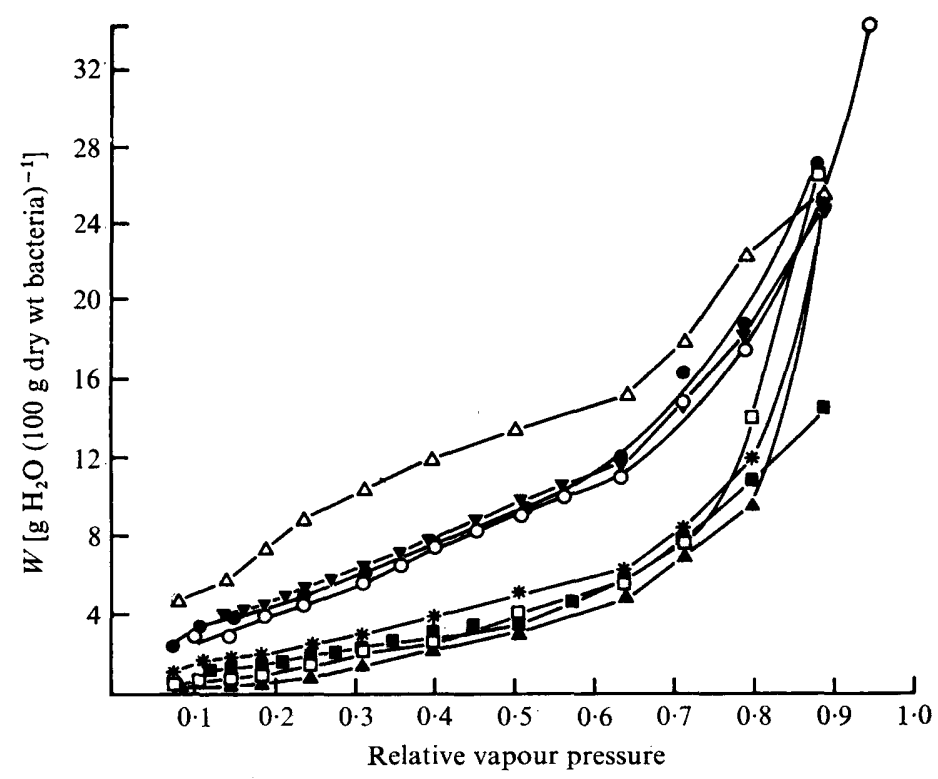

Fig. 2. Water adsorption isotherms at $40^{\circ} \mathrm{C}$ for Ca-montmorillonite and for rhizobia of the $R$. leguminosarum $(\mathrm{L})$ and slow-growing (S) groups. $\triangle$, Ca-montmorillonite; $\nabla, R$. trifolii su297/32B (L); O, R. leguminosarum TAIOI (L); O, R. trifolii SU297/3IA (L); * and $\mathbf{D}, R$. lupini UTI 2 (S); $\square, R$. japonicum QA372 (S); $\Delta, R$. lupini UT2 (S).

Table 3. Compilation of the constants derived by applying the B.E.T. equation to water adsorption isotherm data for various rhizobia and Ca-montmorillonite

$\begin{array}{crc}\begin{array}{c}W_{\mathrm{m}} \\ {[\mathrm{g} \text { water sorbed }} \\ \left.(100 \mathrm{~g})^{-1}\right]\end{array} & C & \begin{array}{c}A \\ \left(\mathrm{~m}^{2} \mathrm{~g}^{-1}\right)\end{array} \\ 4.769 & 14.563 & 167 \cdot 5 \\ 4.710 & 8 \cdot 229 & 165.4 \\ 4.564 & 13.199 & 160.3 \\ 4.68 \mathrm{I} & 11.997 & 164.4 \\ & & \\ 2.707 & 5.790 & 95.06 \\ 2.313 & 3.920 & 81 \cdot 23 \\ \mathrm{r} \cdot 974 & 3.731 & 69.32 \\ 2.803 & 1.829 & 98.43 \\ 2.449 & 3.818 & 86.01 \\ 6.916 & 20.657 & 242.87\end{array}$

R. leguminosarum group

R. trifolii SU297/32B

$R$. trifolii SU297/32B

$R$. leguminosarum TAIOI

Mean for group

Slow-growing group
$R$. lupini UTI 2
R. lupini UTI 2
$R$. lupini UT2
R. japonicum QA372

Mean for group

Ca-montmorillonite $\left.(100 \mathrm{~g})^{-1}\right]$
water sorbed

$20 \cdot 657$

$242 \cdot 87$

$W_{\mathrm{m}}$, Quantity of water required to form a monolayer; $C$, a constant related to the heat of adsorption of the monolayer; $A$, specific surface area of the adsorbing material.

Demirel, I966) and, from the $W_{\mathrm{m}}$ values, the adsorptive surface areas $(A)$ can be calculated. There are consistent differences in the sorptive surface areas calculated in this way for the two groups of rhizobia (Table 3). The average surface area available for water adsorption for the slow-growing group is approximately half that available in the $R$. leguminosarum group.

Because of uncertainties about the validity of values of $A$ obtained using the B.E.T. 


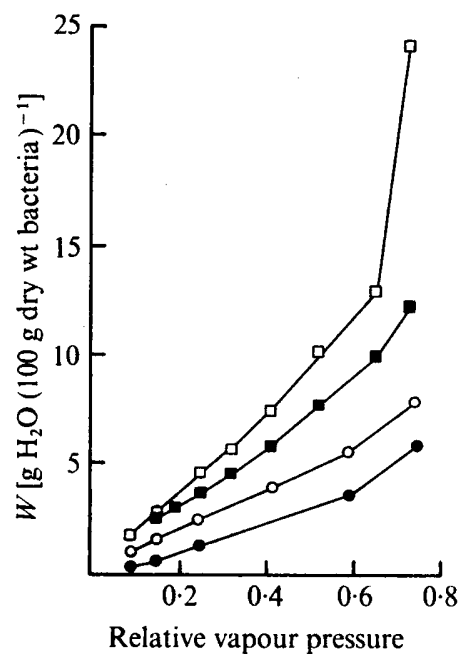

Fig. 3

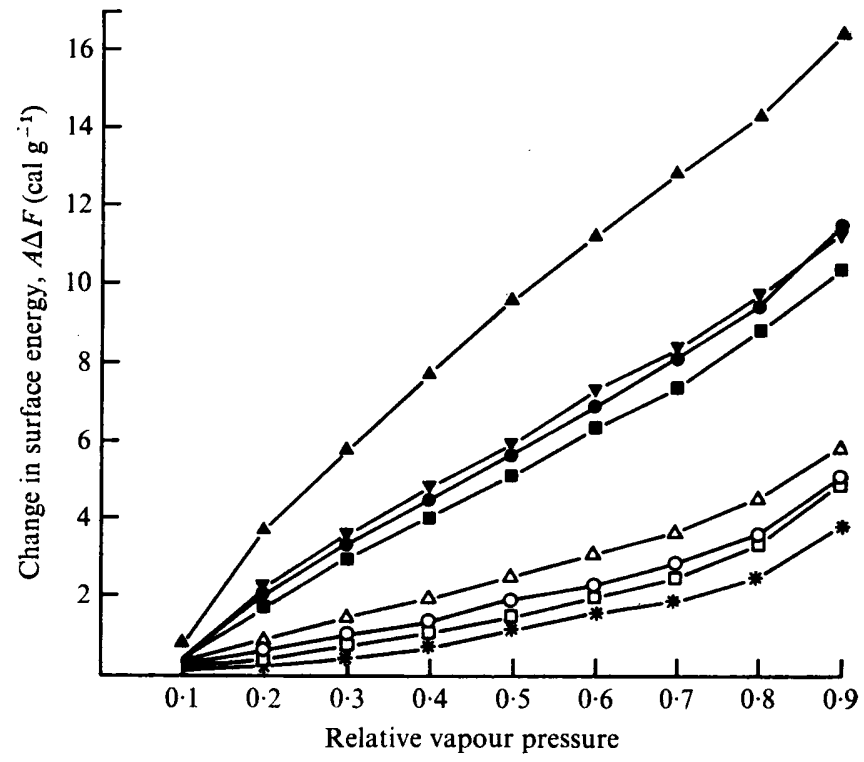

Fig. 4

Fig. 3. Water adsorption isotherms at $40^{\circ} \mathrm{C}$ for Triton X-100 disrupted rhizobia, either dialysed or undialysed. $\square, \boldsymbol{R}$. leguminosarum TaIоI, dialysed; $\boldsymbol{\square}, \boldsymbol{R}$. leguminosarum taIoI, undialysed; $\bigcirc, \boldsymbol{R}$. lupini UT1 2, dialysed; $O, R$. lupini UT1 2, undialysed.

Fig. 4. Change in surface energy $(A \Delta F)$ per $\mathrm{g}$ Ca-montmorillonite or $\mathrm{g}$ bacterial dry wt with change in relative vapour pressure. $\Delta$, Ca-montmorillonite; $O, R$. leguminosarum taIoI; $\nabla$ and $\square, R$. trifolii SU297/3IA; $\triangle$ and $O, R$. lupini UT12; $\square, R$. japonicum QA372; $*, R$. lupini UT2.

equation for adsorption of polar gases to porous solids, Bull (I944) and Sharma, Hehara \& Mann (1969) obtained estimates of the energy involved in wetting various substrates by evaluation of the integral:

$$
A \Delta F=\frac{-R T}{M} \int_{0}^{P ! P_{0}} \frac{W}{P / P_{0}} \mathrm{~d}\left(P / P_{0}\right)
$$

for porous solids. The values obtained for $A \Delta F$ are the free energy changes per gram of solid or the surface energy associated with the adsorption of water at a particular value of $P / P_{0}$. Values for $A \Delta F$ have been obtained for various $P / P_{0}$ levels, and the results show that, at all relative vapour pressures, the surface energies of the $R$. leguminosarum group are greater than those of the slow-growing group (Fig. 4). The surface energy of Ca-montmorillonite is very much greater than those of the rhizobia at all relative vapour pressures.

\section{DISCUSSION}

The studies reported here were undertaken to provide some insight into the variation in desiccation sensitivity observed between two groups of root-nodule bacteria, as well as into the protective effects of montmorillonitic clays on desiccated bacteria. With reservation about extrapolating from these results to actual field soil situations, some interesting features on the water status of the rhizobia have emerged.

Differences in susceptibility to desiccation between the two groups of rhizobia cannot be accounted for by rates of water exchange as little resistance to passage of water molecules 
was observed in both groups of bacteria. This relatively unrestricted water permeability is probably related to the small size of these bacteria. Dick (1966) has postulated that an inverse relationship exists between cell size and rate of water permeability, and this relationship is evident in the comparison made here between micro-organisms of different size. The order of increasing permeability to water in these micro-organisms is: Sacch. cerevisiae $\mathrm{M} 6<$ Bacillus м70 < rhizobia and other small bacteria.

The data derived from water adsorption isotherms indicate that susceptibility to desiccation in these groups of rhizobia is related to the amounts of water retained by the bacteria during desiccation. Greater amounts of water were retained at lower relative vapour pressures by the desiccation-sensitive $R$. leguminosarum group than by the more resistant slow-growing rhizobia, with calculated surface energies showing that bacteria of the former group exhibit a greater affinity for water than those of the latter group. The results obtained suggest that internal osmotic pressure is not important in determining the characteristic isotherms observed in the two groups of bacteria. Since bacteria of the $R$. leguminosarum group possess a greater adsorptive surface area than those of the slow-growing group, it is probable that the isotherm characteristics are determined by differences in the number of water-accessible polar sites on the internal macromolecules of these bacteria.

A lower internal water content at low relative vapour pressures probably imparts greater survival capacity in bacteria by reducing the activity of those enzymes capable of functioning at relatively low water availabilities. The degree of survival of $R$. leguminosarum-type bacteria might be improved by reducing the internal water content of the bacteria at low relative vapour pressures. Amendment of sandy soils with montmorillonite before desiccation results in improved survival of the $R$. leguminosarum group, but not of the slow-growing group (Marshall, 1964; Bushby \& Marshall, 1976).

The suggestion that montmorillonite protects bacteria from the effects of desiccation by altering rates of water loss from the bacteria (Marshall, 1968) is contradicted by the present finding of rapid rates of water permeability that would not be altered significantly by the presence of montmorillonite. Since montmorillonite has a greater affinity for water than the root-nodule bacteria, it is postulated that this clay protects the $R$. leguminosarum bacteria from desiccation by decreasing the internal water content to levels below the equilibrium value attained in the absence of the clay. The equilibrium water content of the slow-growing bacteria may be below some critical value beyond which no further improvement in survival due to reduction of water content can be expected. Obviously, further studies on these bacteria are required before a complete explanation of the observed field response of rhizobia to desiccation and montmorillonite amendments can be satisfactorily explained.

This investigation was supported by grants from the Rural Credits Development Fund of the Reserve Bank of Australia and from the Australian Research Grants Committee. The authors wish to thank Dr R. Outhred and Mr R. Thomas for advice and assistance with n.m.r. techniques.

\section{REFERENCES}

BANGHAM, D. H. (1937). The Gibbs adsorption equation and adsorption on solids. Transactions of the Faraday Society 33, 805-8I I.

Bateman, J. B., Stevens, C. I., Mercer, W. B. \& Carstensen, E. L. (1962). Relative humidity and the killing of bacteria: the variation of cellular water content with external relative humidity or osmolality. Journal of General Microbiology 29, 208-219.

BRUnaUer, S., EMmetT, P. H. \& TELLER, E. (1938). Adsorption of gases in multimolecular layers. Journal of the American Chemical Society 60, 309-319.

Bull, H. B. (1944). Adsorption of water vapor by proteins. Journal of the American Chemical Society 66, 1499-1 507. 
Bull, H. B. \& BREESE, K. (1970). Water and solute binding by proteins. I. Electrolytes. Archives of Biochemistry and Biophysics 137, 299-305.

BushBy, H. V. A. \& MARShal, K. C. (1976). Some factors affecting the survival of root-nodule bacteria on desiccation. Soil Biology and Biochemistry (in the Press).

CONLON, T. \& OUTHRED, R. (1972). Water diffusion permeability of erythrocytes using an NMR technique. Biochimica et biophysica acta 288, 354-36I.

DeVries, A. L., Komatsu, S. K. \& Feeney, R. E. (1970). Chemical and physical properties of freezing pointdepressing glycoproteins from Antarctic fish. Journal of Biological Chemistry 245, 2901-2908.

Dick, D. A. T. (I966). Cell Water. Washington: Butterworths.

Marshall, K. C. (1964). Survival of root-nodule bacteria in dry soils exposed to high temperatures. Australian Journal of Agricultural Research 15, 273-281.

MARShALl, K. C. (1968). The nature of bacterium-clay interactions and its significance in survival of Rhizobium under arid conditions. Transactions of the 9 th International Congress of Soil Science, Adelaide, vol. 3, pp. 275-280. Sydney: Angus \& Robertson.

Pople, J. A., SCHNEIDER, W. G. \& BernsteIn, H. J. (1959). High Resolution Nuclear Magnetic Resonance. New York: McGraw-Hill.

RODERICK, G. L. \& DEMIREL, T. (1966). Water vapor-sodium montmorillonite interaction. Highway Research Record I28, 45-67.

Sharma, M. L., Hehara, G. \& MANn, J. A. (1969). Thermodynamic properties of water adsorbed on dry soil surfaces. Soil Science 107, 86-93.

STEER, B. T. (1973). Dehydration of macromolecules. II. Protective effects of certain anions on ribulosediphosphate carboxylase subjected to low water potentials in vitro. Australian Journal of Biological Sciences 26, 1435-I442.

WALKER, J. E., WolF, M. \& KAPsalis, J. G. (1973). Adsorption of water vapor on myosin A and myosin B. Journal of Agricultural and Food Chemistry 21, 878-880. 